\title{
STUDI PENGGUNAAN DAN PERILAKU MASYARAKAT TERHADAP AIR TANAH PADA MUSIM KEMARAU
}

\author{
Sutrisno \\ Program Studi Teknik Sipil Universitas Muhammadiyah Sorong \\ Jalan pendidikan No.27 Kota Sorong Provinsi Papua Barat \\ Email:soetrisnociung@gmail.com
}

\begin{abstract}
ABSTRAK
Penggunaan air tanah yang kurang baik menyebabkan ketersediaan air alami tidak dapat dipenuhi secara maksimal sepanjang tahun, terlebih pada musim kemarau. Krisis air menjadi masalah yang sulit diantisipasi karena kecenderuangan masyarakat untuk terpaku kepada sumber air konvensional yang rentan mengalami kekeringan, seperti sumur galian dan sumur bor. Penelitian ini bertujuan untuk mengetahui bagaimana cara penggunaan serta pola perilaku konsumsi air yang ada di masyarakat. Dan diharapkan dengan penelitian ini dapat menemukan solusi dari kedua aspek tersebut guna mengatasi masalah krisis air pada musim kemarau. Penelitian ini dilakukan di kelurahan Klaigit, distrik Aimas, Kabupaten Sorong.
\end{abstract}

Kata Kunci : Penggunaan air tanah ; Kemarau ; Kabupaten Sorong.

\section{PENDAHULUAN}

\section{Latar Belakang}

Manusia selalu menempatkan air sebagai kebutuhan yang sangat vital dalam segala kegiatannya seperti aktivitas rumah tangga,pertanian,industri,dan transportasi.Air merupakan kebutuhan yang sangat mendasar bagi umat manusia dan alam sekitarnya. peran air tidsk sksn pernsh lepas dari dalam menopang keberlangsungan hidup manusia.

Begitu pentingnya peran air dalam menopang kehidupan manusia dan sekitarnya, sehingga apabila aspek-aspek pendukung seperti kuantitas dan kualitas serta distribusinya terganggu atau rusak, akan berpengaruh langsung terhadap kehidupan manusia itu sendiri.

Dampak kekeringan terutama sekali terasa pada saat musim kemarau, di saat ketersediaan air dari sumber-sumber alami seperti sumur gali atau sumur borsemakin menipis,disaat seperti ini masyarakat sangat tergantung pada pasokan air bersih dari perusahaan penyedia seperti 
Perusahaan Daerah Air Minum(PDAM). Namum pada kenyataannya upaya pemenuhan kebutuhan tersebut belum maksimal di sebabkan oleh berbagai masalah terutama dalam proses distribusi.

Berdasarkan kenyataan mengenai kebutuhan air dan ketersediaannya yang telah di uraikan, dipandang perlu untuk menganalisa dan menemukan solusi atau berbagai masalah terkait penggunaan air tanah terutama pada sumber-sumber alami, serta pola dan perilaku konsumsi masyarakat terhadap air bersih dimusim kemarau.

\section{Tujuan Penelitian}

Penelitian ini bertujuan untuk mendapatkan solusi mengenai cara penggunaan air tanah yang baik disaat musim kemarau.

\section{STATE OF THE ART}

Adapun penelitian terdahulu yang terkait dengan penelitian ini adalah sebagai berikut :

1. Sasongko, E. B., Widyastuti, E., \& Priyono, R. E. (2014). Kajian kualitas air dan penggunaan sumur gali oleh masyarakat di sekitar Sungai Kaliyasa Kabupaten Cilacap. Jurnal Ilmu Lingkungan, 12(2), 72-82.

2. Kompas. 20 Juni 2005. Cerita Lama, Jakarta Kekurangan Air Bersih. Gramedia, Jakarta.

3. Wahyudi, H. (2009). Kondisi dan Potensi Dampak Pemanfaatan Air Tanah di Kabupaten Bangkalan. Jurnal Aplikasi Teknik Sipil, 7(1), 14-19.

4. Arifaini, N. Sumiharni, Maryanto, A. Hardiyani K. R. 2006. Analisis Fungsi Sumur Resapan terhadap Pengurangan Limpasan di Lingkungan Perkantoran Pemerintah Kota Bandar Lampung. Bandar Lampung. 13 hlm. 


\section{METODE}

\section{Tahapan Penelitian}

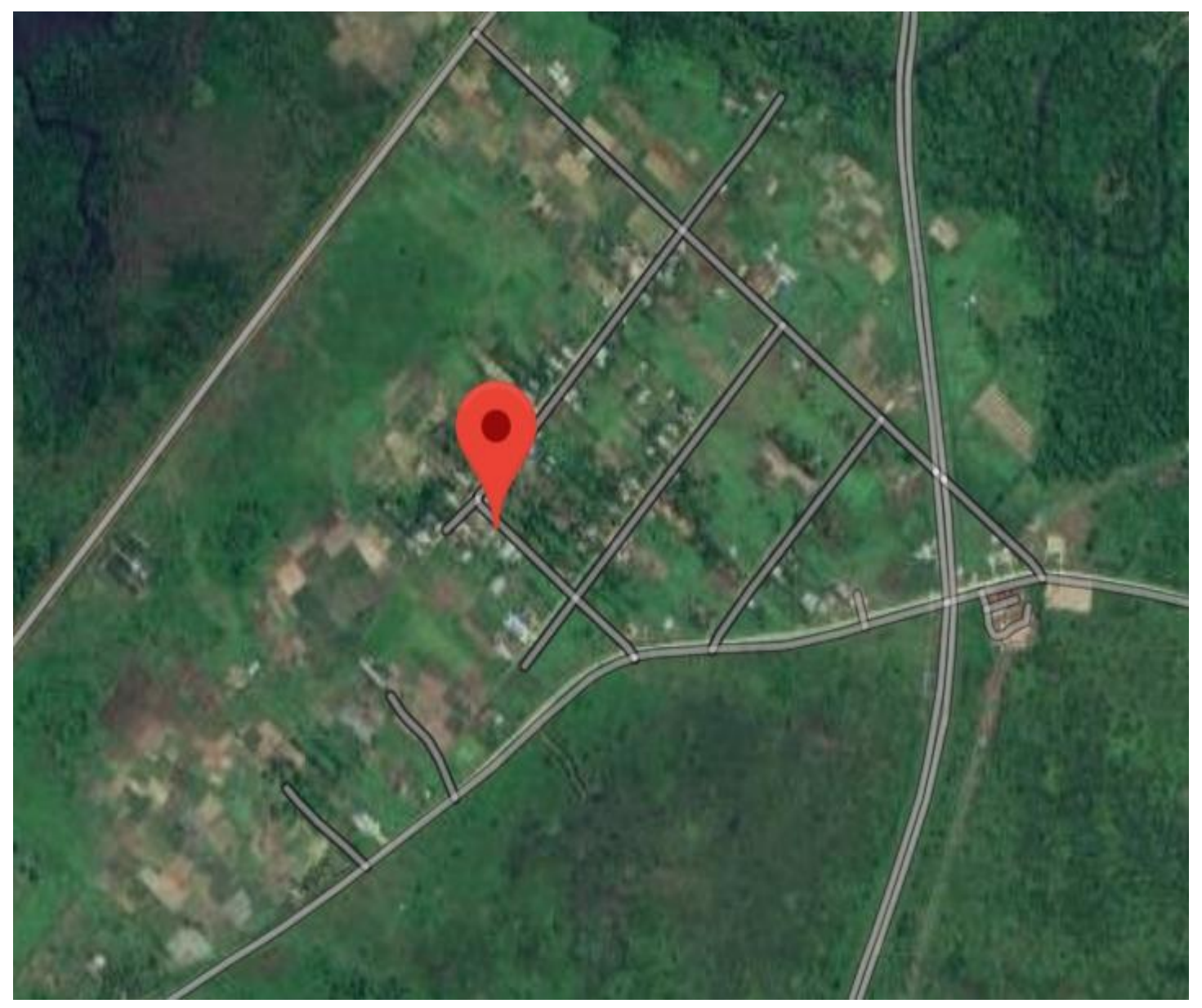

Tahapan penelitian yang digunakan adalah sebagai berikut :

1. Melakukan pengamatan langsung terhadap lokasi penelitian.

2. Melakukan pengambilan data di lokasi penelitian

3. Mengolah data yang didapat guna mendapatkan solusi dari permasalahan penelitian.

Semua metode penulisan dan analisa dalam artikel ilmiah ini merujuk pada panduan penulisan tugas akhir Fakultas Teknik Universitas Muhammadiyah Sorong tahun 2014 (Pristianto, Amri, \& Rusdi, 2014). 


\section{REFERENSI}

1. Kompas. 20 Juni 2005. Cerita Lama, Jakarta Kekurangan Air Bersih. Gramedia, Jakarta.

2. Badan Standardisasi Nasional. 2002. SNI 03-2453-2002, Tata Cara Perencanaan Sumur Resapan Air Hujan untuk Lahan Pekarangan. 20 hlm.

3. Arifaini, N. Sumiharni, Maryanto, A. Hardiyani K. R. 2006. Analisis Fungsi Sumur Resapan terhadap Pengurangan Limpasan di Lingkungan Perkantoran Pemerintah Kota Bandar Lampung. Bandar Lampung. 13 hlm.

4. Wahyudi, H. (2009). Kondisi dan Potensi Dampak Pemanfaatan Air Tanah di Kabupaten Bangkalan. Jurnal Aplikasi Teknik Sipil, 7(1), 14-19.

5. Sasongko, E. B., Widyastuti, E., \& Priyono, R. E. (2014). Kajian kualitas air dan penggunaan sumur gali oleh masyarakat di sekitar Sungai Kaliyasa Kabupaten Cilacap. Jurnal Ilmu Lingkungan, 12(2), 72-82.

6. Subekti, S. (2012). Studi identifikasi kebutuhan dan potensi air baku air minum kabupaten pasuruan. JURNAL ILMIAH MOMENTUM, 8(2). 